\title{
Methionine and Vitamin B6 Intake and Risk of Pancreatic Cancer: A Prospective Study of Swedish Women and Men
}

\section{Citation}

Larsson, Susanna C., Edward Giovannucci, and Alicja Wolk. 2007. "Methionine and Vitamin B6 Intake and Risk of Pancreatic Cancer: A Prospective Study of Swedish Women and Men." Gastroenterology 132 (1): 113-18. https://doi.org/10.1053/j.gastro.2006.10.017.

\section{Permanent link}

http://nrs.harvard.edu/urn-3:HUL.InstRepos:41392113

\section{Terms of Use}

This article was downloaded from Harvard University's DASH repository, and is made available under the terms and conditions applicable to Other Posted Material, as set forth at http:// nrs.harvard.edu/urn-3:HUL.InstRepos:dash.current.terms-of-use\#LAA

\section{Share Your Story}

The Harvard community has made this article openly available. Please share how this access benefits you. Submit a story.

Accessibility 


\title{
Methionine and Vitamin $B_{6}$ Intake and Risk of Pancreatic Cancer: A Prospective Study of Swedish Women and Men
}

\author{
SUSANNA C. LARSSON, ${ }^{*}$ EDWARD GIOVANNUCCI, ${ }^{\star}$ and ALICJA WOLK ${ }^{\star}$
}

${ }^{*}$ Division of Nutritional Epidemiology, National Institute of Environmental Medicine, Karolinska Institutet, Stockholm, Sweden; and ${ }^{\star}$ Departments of Nutrition and Epidemiology, Harvard School of Public Health, and Channing Laboratory, Department of Medicine, Brigham and Women's Hospital and Harvard Medical School, Boston, Massachusetts

\section{See editorial on page 441.}

Background \& Aims: It has been hypothesized that dietary factors involved in methyl group metabolism, such as methionine, folate, and vitamin $B_{6}$, may modify cancer risk. We have previously reported an inverse association between folate intake and pancreatic cancer risk in a prospective population-based cohort of Swedish women and men. In the present study, we used data from this prospective study to examine whether methionine and vitamin $B_{6}$ intakes were associated with the incidence of exocrine pancreatic cancer. Methods: Our study population comprised 81,922 Swedish women and men, aged 45-83 years, who were free from cancer and completed a self-administered food-frequency questionnaire in 1997. We used Cox proportional hazards models to estimate rate ratios with $95 \%$ confidence intervals (CI), adjusted for age, sex, education, smoking, body mass index, diabetes, and intakes of total energy and dietary folate. Results: During a mean follow-up of 7.2 years, through June 2005, 147 incident cases of pancreatic cancer were diagnosed. Methionine intake was significantly inversely associated with risk of pancreatic cancer, whereas no significant association was observed for dietary or total vitamin $B_{6}$ intake. The multivariate rate ratios comparing the highest with the lowest quartile of methionine intake were $0.44(95 \% \mathrm{CI}$, $0.26-0.73 ; P$ for trend $=.0005)$ in women and men combined, $0.59(95 \% \mathrm{CI}, 0.28-1.21 ; P$ for trend $=$ $.07)$ in women, and $0.32(95 \% \mathrm{CI}, 0.15-0.65 ; P$ for trend $=.002)$ in men. Conclusions: These findings suggest that higher methionine intake may reduce the risk of pancreatic cancer.

E vidence from in vitro and animal studies indicates that impaired methyl group metabolism can influence cellular differentiation in the pancreas and contribute to toxic damage in ways that enhance the pathogenesis of pancreatic diseases and carcinogenesis. ${ }^{1}$ Owing to their involvement in methyl group (one-carbon) metab- olism, methionine, folate, and vitamin $\mathrm{B}_{6}$ may play a role in pancreatic carcinogenesis. Methionine is the precursor of $S$-adenosylmethionine, the universal methyl group donor in biologic methylation reactions. ${ }^{2}$ Folate, in the form of 5-methyltetrahydrofolate, serves as the methyl group donor for the remethylation of homocysteine to methionine. Another form of folate, 5,10-methylenetetrahydrofolate, provides the methyl group for the conversion of uracil to thymidylate needed for DNA synthesis and repair. Vitamin $B_{6}$ is a coenzyme for serine hydroxymethyltransferase, which catalyzes the formation of 5,10-methylenetetrahydrofolate.

We have previously reported an inverse association between dietary folate intake and incidence of pancreatic cancer in the Swedish Mammography Cohort and the Cohort of Swedish Men. ${ }^{3}$ Other prospective cohort studies $^{4-6}$ and one case-control study ${ }^{7}$ have also observed an inverse association of dietary folate intake or serum folate levels with risk of pancreatic cancer. Only one previous study has, to our knowledge, examined methionine and vitamin $\mathrm{B}_{6}$ in relation to risk of pancreatic cancer. ${ }^{4,5}$ In that prospective study of Finnish male smokers, no association was found with methionine and vitamin $B_{6}$ intakes ${ }^{5}$; however, serum levels of pyridoxal-5' -phosphate (the coenzyme form of vitamin $\mathrm{B}_{6}$ ) were statistically significantly inversely associated with risk of pancreatic cancer. ${ }^{4}$

The purpose of the present study was to examine intakes of methionine and vitamin $\mathrm{B}_{6}$ in relation to the incidence of pancreatic cancer in the Swedish Mammography Cohort and Cohort of Swedish Men. Because alcohol and cigarette smoking may influence methyl group availability, ${ }^{8-11}$ we also investigated whether the association between methionine and vitamin $\mathrm{B}_{6}$ intake and risk of pancreatic cancer was modified by alcohol consumption and smoking.

Abbreviations used in this paper: $\mathrm{Cl}$, confidence interval; MTHFR, 5,10-methylenetetrahydrofolate reductase; $\mathrm{RR}$, rate ratio.

(C) 2007 by the AGA Institute 0016-5085/07/\$32.00 doi:10.1053/j.gastro.2006.10.017 


\section{Materials and Methods}

\section{Study Population}

The Swedish Mammography Cohort was established between 1987 and 1990, when all women born between 1914 and 1948 and residing in central Sweden (Västmanland and Uppsala counties) were mailed a questionnaire on diet, weight, height, and education. In the autumn of 1997, all living participants received a new questionnaire that was expanded to include about 350 items concerning diet and other lifestyle factors (including cigarette smoking), dietary supplement use, and medical history; 39,227 women returned a completed questionnaire (70\% response rate). The Cohort of Swedish Men began in the autumn of 1997, when all men born between 1918 and 1952 and residing in central Sweden (Västmanland and Örebro counties) received a questionnaire that was identical (except for some sex-specific questions) to the Swedish Mammography Cohort questionnaire from 1997; 48,850 men answered the questionnaire ( $49 \%$ response rate).

Eligible for inclusion in the present analyses were respondents to the 1997 questionnaire. We excluded participants with implausibly low or high total energy intake (ie, 3 SDs from the $\log _{\mathrm{e}}$-transformed mean energy intake in women and men separately), those with erroneous or missing national registration number, and those with cancer (except nonmelanoma skin cancer) diagnosed before baseline. The final study population consisted of 81,922 participants (36,616 women and 45,306 men) aged 45- 83 years in 1997. The study was approved by the Regional Ethical Review Board in Stockholm, Sweden.

\section{Dietary Assessment}

A 96-item food-frequency questionnaire was administered in 1997 to assess average dietary intake during the previous year. Eight categories for frequency of consumption were provided, ranging from "never" to " 3 or more times per day." Intakes of nutrients were calculated by multiplying the average frequency of consumption of each food by the nutrient content of age- and sex-specific portion sizes using food composition values obtained from the Swedish Food Administration Database. ${ }^{12}$ All nutrient intakes were energy adjusted using the residual method. ${ }^{13}$ The questionnaire also elicited data on dietary supplement use, including vitamin $\mathrm{B}_{6}$ supplements, Bvitamin complex, and multivitamins. Total vitamin $\mathrm{B}_{6}$ intake was calculated by summing intake from foods and vitamin supplements. In a validity study of the foodfrequency questionnaire among 248 men in the study area, the Spearman correlation coefficient for total vitamin $B_{6}$ intake between the average of fourteen 24-hour recall interviews and the food-frequency questionnaire was $0.65 .{ }^{14}$ Data on methionine intake were not available from recall interviews.

\section{Case Ascertainment and Follow-up}

We identified incident cases of pancreatic cancer (International Classification of Diseases, Ninth Revision, code 157) by computerized linkage with the national and regional Swedish cancer registers, both of which provide almost $100 \%$ case ascertainment in Sweden. ${ }^{15}$ Islet cell carcinomas (International Classification of Diseases, Ninth Revision, code 157.4) were not included as cases, because their etiology may be different from that of the exocrine pancreas. We obtained information on dates of death and migration by computerized linkage to the Swedish Death and Population registers at Statistics Sweden.

\section{Statistical Analysis}

For each participant, person-years of follow-up were counted from January 1, 1998, to the date of diagnosis of pancreatic cancer, death from any cause, migration, or June 30, 2005, whichever occurred first. We used Cox proportional hazards models ${ }^{16}$ to estimate rate ratios (RRs) with 95\% confidence intervals (CIs). Age was used as the underlying time metric, with entry and exit time defined as the subject's age at baseline and age at diagnosis of pancreatic cancer or censoring, respectively. Sex was controlled for as a stratum variable in the Cox model to allow for different baseline hazard rates. All multivariate analyses were further adjusted for education, smoking status and pack-years of smoking (the average number of cigarette packs smoked per day multiplied by the number of years of smoking), body mass index, history of diabetes, and intakes of total energy and dietary folate. We also considered adjustment for other potential confounders, including physical activity, aspirin use, vitamin supplement use, and intakes of alcohol, red meat, coffee, and tea; however, because adjustment for these variables did not alter the risk estimates, they were not included in the final multivariate models. We tested the proportional hazards assumption for each nutrient intake variable in relation to risk of pancreatic cancer using the likelihood ratio test, comparing nested models with and without product terms for nutrient intake and follow-up time. There was no evidence of violation of the proportional hazards assumption.

Tests for linear trend were conducted using the median value for each quartile of nutrient intake as a continuous variable. We evaluated whether the relation between nutrient intake and pancreatic cancer was modified by smoking (never vs ever smoker) and alcohol intake (using as a cut point the median intake in this cohort, ie, $<5$ $\mathrm{g} /$ day vs $\geq 5 \mathrm{~g} /$ day). To assess the significance of the interactions, we created cross-product terms between nutrient intake and smoking or alcohol intake. All statistical analyses were performed with SAS software, release 9.1 (SAS Institute, Inc, Cary, NC). All statistical tests were 2-sided. 
Table 1. Baseline Characteristics of the Study Population According to Sex and Quartiles of Intake of Methionine and Dietary and Total Vitamin $\mathrm{B}_{6}$

\begin{tabular}{|c|c|c|c|c|c|c|}
\hline \multirow[b]{2}{*}{ Characteristic } & \multicolumn{2}{|c|}{ Methionine $^{a}$} & \multicolumn{2}{|c|}{ Dietary vitamin $\mathrm{B}_{6}{ }^{a}$} & \multicolumn{2}{|c|}{ Total vitamin $\mathrm{B}_{6}{ }^{a, b}$} \\
\hline & $\begin{array}{c}\text { Quartile } \\
1\end{array}$ & $\begin{array}{c}\text { Quartile } \\
4\end{array}$ & $\begin{array}{c}\text { Quartile } \\
1\end{array}$ & $\begin{array}{c}\text { Quartile } \\
4\end{array}$ & $\begin{array}{c}\text { Quartile } \\
1\end{array}$ & $\begin{array}{c}\text { Quartile } \\
4\end{array}$ \\
\hline \multicolumn{7}{|l|}{ Women $(n=36,616)$} \\
\hline Age $(y)$ & 62.4 & 61.7 & 63.5 & 60.5 & 63.6 & 61.1 \\
\hline Postsecondary education (\%) & 17.7 & 20.4 & 16.1 & 20.0 & 14.0 & 23.5 \\
\hline \multicolumn{7}{|l|}{ Smoking status } \\
\hline Never smoker (\%) & 54.7 & 51.2 & 50.8 & 54.1 & 50.9 & 53.9 \\
\hline Past smoker (\%) & 21.9 & 24.3 & 20.5 & 25.3 & 20.4 & 25.3 \\
\hline Current smoker (\%) & 23.4 & 24.4 & 28.7 & 20.7 & 28.6 & 20.9 \\
\hline Body mass index $\left(\mathrm{kg} / \mathrm{m}^{2}\right)$ & 24.6 & 25.4 & 24.8 & 25.2 & 25.0 & 24.8 \\
\hline Diabetes (\%) & 2.2 & 5.5 & 2.7 & 4.8 & 2.9 & 3.7 \\
\hline Multivitamin use $(\%)^{c}$ & 36.4 & 38.3 & 32.5 & 40.7 & 0.2 & 82.1 \\
\hline Vitamin $\mathrm{B}_{6}$ supplement use (\%) & 9.3 & 8.5 & 7.4 & 9.2 & 0.0 & 20.8 \\
\hline Total energy intake (kcal/day) & 1762 & 1739 & 1770 & 1772 & 1742 & 1772 \\
\hline Dietary folate intake $(\mu g / \text { day })^{a}$ & 306 & 345 & 252 & 396 & 257 & 367 \\
\hline \multicolumn{7}{|l|}{ Men $(n=45,306)$} \\
\hline Age $(y)$ & 60.7 & 60.3 & 61.9 & 59.3 & 61.5 & 60.4 \\
\hline Postsecondary education (\%) & 15.3 & 15.9 & 12.4 & 19.1 & 11.5 & 23.0 \\
\hline \multicolumn{7}{|l|}{ Smoking status } \\
\hline Never smoker (\%) & 36.3 & 33.6 & 33.7 & 37.1 & 34.0 & 37.7 \\
\hline Past smoker (\%) & 38.9 & 39.1 & 36.2 & 41.3 & 36.4 & 40.5 \\
\hline Current smoker (\%) & 24.8 & 27.3 & 30.1 & 21.7 & 29.7 & 21.8 \\
\hline Body mass index $\left(\mathrm{kg} / \mathrm{m}^{2}\right)$ & 25.4 & 26.4 & 25.7 & 25.9 & 25.8 & 25.5 \\
\hline Diabetes (\%) & 3.9 & 10.2 & 4.3 & 9.3 & 4.5 & 6.9 \\
\hline Multivitamin use $(\%)^{c}$ & 18.7 & 19.9 & 16.3 & 24.1 & 1.9 & 80.0 \\
\hline Vitamin $\mathrm{B}_{6}$ supplement use (\%) & 3.8 & 4.0 & 3.2 & 5.0 & 0.0 & 16.9 \\
\hline Total energy intake ( $k c a l / d a y)$ & 2674 & 2655 & 2730 & 2623 & 2714 & 2708 \\
\hline Dietary folate intake $(\mu g / \text { day })^{a}$ & 245 & 281 & 215 & 324 & 219 & 300 \\
\hline
\end{tabular}

NOTE. All variables (except age) are age standardized.

aNutrient intakes are energy adjusted using the residual method. ${ }^{13}$

${ }^{b}$ Total intake from foods and vitamin supplements.

${ }^{c}$ Regular or occasional use of multivitamin supplements.

${ }^{d}$ Specific vitamin $B_{6}$ supplements (containing vitamin $B_{6}$ only) and B-complex vitamins.

\section{Results}

As of June 30, 2005 (mean follow-up, 7.2 years), 147 participants (65 women and 82 men) had been diagnosed with exocrine pancreatic cancer. Compared with women and men in the lowest quartile of methionine intake, those in the highest quartile were more likely to have a history of diabetes and had a higher folate intake (Table 1). Those in the highest quartiles of dietary and total vitamin $B_{6}$ intakes were, on average, younger and more likely to have a postsecondary education, to be nonsmokers, to have diabetes, and to use multivitamins and vitamin $\mathrm{B}_{6}$ supplements than those in the lowest quartiles of vitamin $\mathrm{B}_{6}$ intake.

Methionine intake was significantly inversely associated with risk of pancreatic cancer, whereas no significant association was observed for dietary or total vitamin $\mathrm{B}_{6}$ intakes (Table 2). The multivariate RRs for the highest compared with the lowest quartile of methionine intake were $0.44(95 \% \mathrm{CI}, 0.26-0.73 ; P$ for trend $=.0005)$ in women and men combined, 0.59 (95\% CI, 0.28-1.21; $P$ for trend $=.07)$ in women, and $0.32(95 \% \mathrm{CI}, 0.15-0.65$; $P$ for trend $=.002$ ) in men. Among women and men combined, results for methionine intake were similar after excluding cases diagnosed within the first 2 years of follow-up (RR, 0.46; 95\% CI, 0.26-0.81) or those with a history of diabetes (RR, 0.49; 95\% CI, $0.29-0.85$ ). The sexand age-adjusted yearly incidence rates were 35 and 15 per 100,000 individuals in the lowest and highest quartiles of methionine intake.

The inverse association between methionine intake and risk of pancreatic cancer was more pronounced in never smokers (highest vs lowest quartile: multivariate RR, 0.15; 95\% CI, 0.05-0.52) than in ever smokers (corresponding $\mathrm{RR}, 0.64 ; 95 \% \mathrm{CI}, 0.36-1.15$ ), although a test for interaction was not statistically significant $\left(P_{\text {interaction }}\right.$ $=.06$ ). There was no statistically significant interaction between smoking status and vitamin $\mathrm{B}_{6}$ intake, or between alcohol consumption and methionine or vitamin $\mathrm{B}_{6}$ intake, in relation to pancreatic cancer $\left(P_{\text {interaction }}>.20\right.$ for all). When intakes of methionine and dietary folate were evaluated jointly, the multivariate RR of pancreatic cancer was 0.33 (95\% CI, 0.19-0.59) for women and men with high intakes of both methionine (highest tertile) and dietary folate (above the median value in the cohort) 
Table 2. RRs of Pancreatic Cancer According to Quartiles of Intake of Methionine and Dietary and Total Vitamin $B_{6}$

\begin{tabular}{|c|c|c|c|c|c|}
\hline \multirow[b]{2}{*}{ Nutrient } & \multicolumn{4}{|c|}{ Quartile of intake } & \multirow[b]{2}{*}{$P$ for trend ${ }^{a}$} \\
\hline & 1 (lowest) & 2 & 3 & 4 (highest) & \\
\hline \multicolumn{6}{|l|}{ Methionine } \\
\hline Intake (g/day) & $<1.59(1.46)$ & $1.59-1.78$ (1.69) & $1.79-2.01$ (1.89) & $\geq 2.02(2.21)$ & \\
\hline $\begin{array}{l}\text { No. of pancreatic } \\
\text { cancer cases }\end{array}$ & 52 & 43 & 29 & 23 & \\
\hline $\begin{array}{l}\text { Person-years of } \\
\text { follow-up }\end{array}$ & 147,021 & 148,197 & 148,556 & 147,423 & \\
\hline $\begin{array}{l}\text { Age- and sex-adjusted } \\
\text { RR }(95 \% \mathrm{Cl})\end{array}$ & 1.00 & $0.85(0.57-1.28)$ & $0.59(0.37-0.92)$ & $0.46(0.28-0.76)$ & .0007 \\
\hline $\begin{array}{l}\text { Multivariate RR }(95 \% \\
\mathrm{Cl})^{b}\end{array}$ & 1.00 & 0.89 (0.59-1.34) & $0.60(0.37-0.95)$ & $0.44(0.26-0.73)$ & .0005 \\
\hline \multicolumn{6}{|l|}{ Dietary vitamin $\mathrm{B}_{6}$} \\
\hline $\begin{array}{l}\text { Intake (mg/day) } \\
\text { (median) }\end{array}$ & $<1.77$ (1.63) & $1.77-1.97$ (1.88) & $1.98-2.21(2.09)$ & $\geq 2.22$ (2.44) & \\
\hline $\begin{array}{l}\text { No. of pancreatic } \\
\text { cancer cases }\end{array}$ & 50 & 41 & 24 & 32 & \\
\hline $\begin{array}{l}\text { Person-years of } \\
\text { follow-up }\end{array}$ & 145,968 & 148,174 & 148,515 & 148,540 & \\
\hline $\begin{array}{l}\text { Age- and sex-adjusted } \\
\text { RR }(95 \% \mathrm{Cl})\end{array}$ & 1.00 & $0.89(0.59-1.35)$ & $0.56(0.34-0.91)$ & $0.78(0.50-1.22)$ & .14 \\
\hline $\begin{array}{l}\text { Multivariate RR }(95 \% \\
\quad \mathrm{Cl})^{b}\end{array}$ & 1.00 & $1.00(0.65-1.55)$ & $0.67(0.39-1.15)$ & $0.98(0.57-1.69)$ & .72 \\
\hline \multicolumn{6}{|l|}{ Total vitamin $\mathrm{B}_{6}$} \\
\hline Intake (mg/day) & $<1.83(1.67)$ & $1.83-2.08$ (1.95) & $2.09-2.55(2.26)$ & $\geq 2.56(3.43)$ & \\
\hline $\begin{array}{l}\text { No. of pancreatic } \\
\text { cancer cases }\end{array}$ & 44 & 35 & 30 & 38 & \\
\hline $\begin{array}{l}\text { Person-years of } \\
\text { follow-up }\end{array}$ & 146,100 & 147,990 & 148,566 & 148,541 & \\
\hline $\begin{array}{l}\text { Age- and sex-adjusted } \\
\text { RR }(95 \% \mathrm{Cl})\end{array}$ & 1.00 & 0.89 (0.57-1.39) & $0.81(0.51-1.29)$ & $0.99(0.64-1.54)$ & .86 \\
\hline $\begin{array}{l}\text { Multivariate RR }(95 \% \\
\quad \mathrm{Cl})^{b}\end{array}$ & 1.00 & $1.04(0.65-1.66)$ & $1.01(0.61-1.68)$ & $1.23(0.76-1.99)$ & .36 \\
\hline
\end{tabular}

ap values for trend were obtained from 2-sided Wald tests.

${ }^{b}$ Multivariate RRs are from Cox proportional hazards models adjusted for age, sex, education (less than high school, high school graduate, or more than high school), smoking status and pack-years of smoking (never, past $<20$ pack-years, past $\geq 20$ pack-years, current $<20$ pack-years, current 20-39 pack-years, or current $\geq 40$ pack-years), body mass index $\left(<25.0,25.0-29.9\right.$, or $\left.\geq 30 \mathrm{~kg} / \mathrm{m}^{2}\right)$, diabetes (yes $\left./ \mathrm{no}\right)$, and intakes of total energy (continuous) and dietary folate (quartiles).

compared with those with low intakes of both nutrients (Figure 1).

\section{Discussion}

In this prospective study of Swedish women and men, we observed an inverse dose-response relationship between methionine intake and risk of pancreatic cancer. Foods rich in methionine include fish, poultry, meat, legumes, and dairy products. No association was found between intake of vitamin $B_{6}$ and risk of pancreatic cancer.

Strengths of our study include its prospective and population-based design, high rates of follow-up, and detailed information on diet as well as potential risk factors for pancreatic cancer. The prospective study design precluded recall and selection bias, and the practically complete follow-up minimizes the possibility that differential follow-up affected our results. A limitation of our study is that estimates of nutrient intake calculated from the dietary questionnaire are subject to measurement error. However, because diet was assessed before the diagnosis of pancreatic cancer, such error would have been nondifferential, and random nondifferential misclassification would tend to attenuate any true association. Because our study was observational, we cannot exclude the possibility that the observed inverse relation between methionine intake and pancreatic cancer is due to confounding by certain dietary patterns or other factors associated with methionine intake or is attributable to other nutrients or combinations of nutrients in methionine-rich foods. Although we were unable to control for chronic pancreatitis, it is unlikely that lack of adjustment for this factor contributed to our findings because pancreatitis may account for only a small proportion of the total number of pancreatic cancer cases. ${ }^{17}$

Biological plausibility for a relation between methyl group-deficient diets and risk of pancreatic cancer includes a high, specific requirement for methyl group 


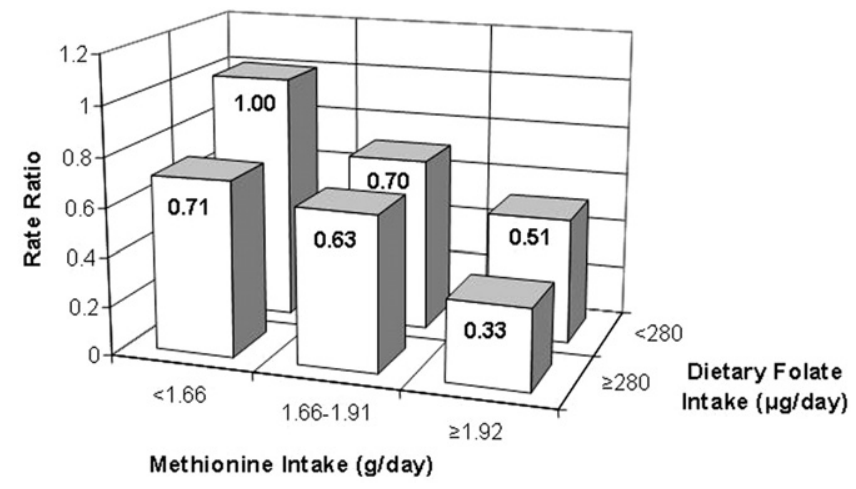

Figure 1. Multivariate RRs of pancreatic cancer according to intakes of methionine (tertiles) and dietary folate (above/below the median). The RRs are from Cox proportional hazards models adjusted for age, sex, education (less than high school, high school graduate, or more than high school), smoking status and pack-years of smoking (never, past $<20$ pack-years, past $\geq 20$ pack-years, current $<20$ pack-years, current 20-39 pack-years, or current $\geq 40$ pack-years), body mass index $\left(<25.0,25.0-29.9\right.$, or $\left.\geq 30 \mathrm{~kg} / \mathrm{m}^{2}\right)$, diabetes (yes/no), and total energy intake (continuous). The $6 \mathrm{RRs}(95 \% \mathrm{Cls})$ are as follows: 1.00 (reference), 0.70 (0.43-1.14), 0.51 (0.29-0.90), 0.71 (0.41-1.23), 0.63 (0.37-1.05), and $0.33(0.19-0.59)$.

donors ${ }^{18,19}$; the pancreas contains high levels of folate derivates, including 5-methyltetrahydrofolate, which is the product of the reaction catalyzed by 5,10-methylenetetrahydrofolate reductase (MTHFR). 5-Methyltetrahydrofolate serves as the methyl group donor for the remethylation of homocysteine to methionine, thereby ensuring the provision of $S$-adenosylmethionine necessary for biologic methylation reactions, including DNA methylation. Aberrant DNA methylation patterns may contribute to carcinogenesis, possibly by influencing genomic stability, gene expression, and the susceptibility of genes to muations. ${ }^{20,21}$ Animals fed diets deficient in methyl group donors (methionine and choline) have altered pancreatic acinar cell differentiation ${ }^{19,22}$ and impaired exocrine function of the pancreas..23,24 Furthermore, animals treated with ethionine, an inhibitor of cellular methylation reactions, develop acute pancreatitis. ${ }^{25,26}$ Supplementation with dietary methionine has also been shown to suppress the development of pancreatic cancer in the postinitiation phase of pancreatic carcinogenesis in hamsters. ${ }^{27}$ A possible role of reduced methyl group availability in pancreatic carcinogenesis is further supported by recent findings from 2 case-control studies showing that a functional polymorphism of the MTHFR gene, C677T, modified the risk of pancreatic cancer. ${ }^{28,29}$ The 2 studies reported that individuals carrying the MTHFR $677 T T$ (variant) genotype, which is associated with decreased enzyme activity, lower plasma folate levels, and elevated plasma homocysteine levels, ${ }^{30,31}$ had a statistically significant approximately 2 - to 5 -fold higher risk of pancreatic cancer compared with individuals with the 677CC genotype. ${ }^{28,29}$ Another case-control study found no relation between the MTHFR C677T poly- morphism and risk of pancreatic cancer. ${ }^{32}$ However, separate analyses in the same study ${ }^{32}$ showed that pancreatic cancers with reduced MTHFR function due to loss of an MTHFR allele had more DNA hypomethylation and more chromosomal deletions.

Besides methionine, folate, and vitamin $\mathrm{B}_{6}$, other dietary factors such as alcohol (a methyl group antagonist $\left.{ }^{8,9}\right)$ and vitamin $B_{12}$ may influence methyl group availability. In this study, we found no interaction between alcohol consumption and vitamin $\mathrm{B}_{6}$ or methionine intake in relation to risk of pancreatic cancer. However, the low consumption of alcohol in our study population limited our ability to examine the influence of methionine and vitamin $B_{6}$ at high levels of alcohol intake. Vitamin $B_{12}$ is a coenzyme for methionine synthase and is important for maintaining adequate intracellular levels of methionine. We did not consider vitamin $B_{12}$ in this study because in a reasonably well-nourished population, low vitamin $B_{12}$ status is caused almost entirely by poor intestinal absorption rather than inadequate dietary intake. $^{33}$ A prospective study of Finnish male smokers showed no association between serum vitamin $B_{12}$ levels and risk of pancreatic cancer. ${ }^{4}$ Some studies, ${ }^{34-36}$ but not all, ${ }^{37}$ have found an excess risk of pancreatic cancer among patients with pernicious anemia (vitamin $\mathrm{B}_{12}$ deficiency). Cigarette smoke may influence methyl group availability by reducing folate, vitamin $\mathrm{B}_{6}$, and vitamin $\mathrm{B}_{12}$ status. ${ }^{10,11}$ In the present study, the inverse relation between intake of methionine and risk of pancreatic cancer was stronger in never smokers than in ever smokers.

In summary, the results from this prospective study suggest that higher intake of methionine may reduce the risk of pancreatic cancer. This finding lends further support to the hypothesis that reduced methyl group availability may play a role in pancreatic carcinogenesis.

\section{References}

1. Longnecker DS. Abnormal methyl metabolism in pancreatic toxicity and diabetes. J Nutr 2002;132:2373S-2376S.

2. Choi SW, Mason JB. Folate and carcinogenesis: an integrated scheme. J Nutr 2000;130:129-132.

3. Larsson SC, Håkansson N, Giovannucci E, Wolk A. Folate intake and pancreatic cancer incidence: a prospective study of Swedish women and men. J Natl Cancer Inst 2006;98:407-413.

4. Stolzenberg-Solomon RZ, Albanes D, Nieto FJ, Hartman TJ, Tangrea JA, Rautalahti M, Sehlub J, Virtamo J, Taylor PR. Pancreatic cancer risk and nutrition-related methyl-group availability indicators in male smokers. J Natl Cancer Inst 1999;91:535-541.

5. Stolzenberg-Solomon RZ, Pietinen P, Barrett MJ, Taylor PR, Virtamo J, Albanes D. Dietary and other methyl-group availability factors and pancreatic cancer risk in a cohort of male smokers. Am J Epidemiol 2001;153:680-687.

6. Skinner HG, Michaud DS, Giovannucci EL, Rimm EB, Stampfer MJ, Willett WC, Colditz GA, Fuchs CS. A prospective study of folate intake and the risk of pancreatic cancer in men and women. Am J Epidemiol 2004;160:248-258.

7. Baghurst PA, McMichael AJ, Slavotinek AH, Baghurst KI, Boyle P, Walker AM. A case-control study of diet and cancer of the pancreas. Am J Epidemiol 1991;134:167-179. 
8. Finkelstein JD, Cello JP, Kyle WE. Ethanol-induced changes in methionine metabolism in rat liver. Biochem Biophys Res Commun 1974;61:525-531.

9. Barak AJ, Beckenhauer HC, Tuma DJ, Badakhsh S. Effects of prolonged ethanol feeding on methionine metabolism in rat liver. Biochem Cell Biol 1987;65:230-233.

10. Piyathilake CJ, Macaluso M, Hine RJ, Richards EW, Krumdieck CL. Local and systemic effects of cigarette smoking on folate and vitamin B-12. Am J Clin Nutr 1994;60:559-566.

11. Gabriel HE, Crott JW, Ghandour H, Dallal GE, Choi SW, Keyes MK, Jang $\mathrm{H}$, Liu Z, Nadeau M, Johnston A, Mager D, Mason JB. Chronic cigarette smoking is associated with diminished folate status, altered folate form distribution, and increased genetic damage in the buccal mucosa of healthy adults. Am J Clin Nutr 2006;83:835-841.

12. Bergström L, Kylberg E, Hagman U, Erikson H, Bruce A.. The food composition database KOST: the National Administration's information system for nutritive values of food. Vår Föda 1991;43: 439-447.

13. Willett W, Stampfer MJ. Total energy intake: implications for epidemiologic analyses. Am J Epidemiol 1986;124:17-27.

14. Messerer M, Johansson SE, Wolk A. The validity of questionnairebased micronutrient intake estimates is increased by including dietary supplement use in Swedish men. J Nutr 2004;134: 1800-1805.

15. Mattsson B, Wallgren A. Completeness of the Swedish Cancer Register. Non-notified cancer cases recorded on death certificates in 1978. Acta Radiol Oncol 1984;23:305-313.

16. Cox DR. Regression models and life tables (with discussion). J R Stat Soc (B) 1972;34:187-220.

17. Lowenfels AB, Maisonneuve P. Pancreatic cancer: development of a unifying etiologic concept. Ann N Y Acad Sci 1999;880:191200.

18. Balaghi M, Wagner C. Methyl group metabolism in the pancreas of folate-deficient rats. J Nutr 1992;122:1391-1396.

19. Hoover KL, Poirier LA. Hepatocyte-like cells within the pancreas of rats fed methyl-deficient diets. J Nutr 1986;116:1569-1575.

20. Chen RZ, Pettersson U, Beard C, Jackson-Grusby L, Jaenisch R. DNA hypomethylation leads to elevated mutation rates. Nature 1998;395:89-93.

21. Kim YI. Folate and DNA methylation: a mechanistic link between folate deficiency and colorectal cancer? Cancer Epidemiol Biomarkers Prev 2004;13:511-519.

22. Parsa I, Marsh WH, Fitzgerald PJ. Pancreas acinar cell differentiation. VI. Effects of methyl donors and homocysteine. Fed Proc 1972;31:166-175.

23. Balaghi M, Horne DW, Woodward SC, Wagner C. Pancreatic one-carbon metabolism in early folate deficiency in rats. Am J Clin Nutr 1993;58:198-203.

24. Balaghi M, Wagner C. Folate deficiency inhibits pancreatic amylase secretion in rats. Am J Clin Nutr 1995;61:90-96.

25. Farber E, Popper H. Production of acute pancreatitis with ethionine and its prevention by methionine. Proc Soc Exp Biol Med 1950;74:838-840.
26. Goldberg RC, Chaikoff IL, Dodge AH. Destruction of pancreatic acinar tissue by DL-ethionine. Proc Soc Exp Biol Med 1950;74: 869-872.

27. Furukawa F, Nishikawa A, Lee IS, Son HY, Nakamura H, Miyauchi $M$, Takahashi M, Hirose M. Inhibition by methionine of pancreatic carcinogenesis in hamsters after initiation with $\mathrm{N}$-nitrosobis(2 oxopropyl) amine. Cancer Lett 2000;152:163-167.

28. Li D, Ahmed M, Li Y, Jiao L, Chou TH, Wolff RA, Lenzi R, Evans DB, Bondy ML, Pisters PW, Abbruzzese JL, Hassan MM. 5,10-methylenetetrahydrofolate reductase polymorphisms and the risk of pancreatic cancer. Cancer Epidemiol Biomarkers Prev 2005;14: 1470-1476.

29. Wang L, Miao X, Tan W, Lu X, Zhao P, Zhao X, Shan Y, Li H, Lin D. Genetic polymorphisms in methylenetetrahydrofolate reductase and thymidylate synthase and risk of pancreatic cancer. Clin Gastroenterol Hepatol 2005;3:743-751.

30. Frosst P, Blom HJ, Milos R, Goyette P, Sheppard CA, Matthews RG, Boers GJ, den Heijer M, Kluijtmans LA, van den Heuvel LP, et al. A candidate genetic risk factor for vascular disease: a common mutation in methylenetetrahydrofolate reductase. Nat Genet 1995;10:111-113.

31. Klerk M, Verhoef P, Clarke R, Blom HJ, Kok FJ, Schouten EG. MTHFR $677 \mathrm{C} \rightarrow$ T polymorphism and risk of coronary heart disease: a meta-analysis. JAMA 2002;288:2023-2031.

32. Matsubayashi H, Skinner HG, lacobuzio-Donahue C, Abe T, Sato N, Riall TS, Yeo CJ, Kern SE, Goggins M. Pancreaticobiliary cancers with deficient methylenetetrahydrofolate reductase genotypes. Clin Gastroenterol Hepatol 2005;3:752-760.

33. Selhub J, Jacques PF, Wilson PW, Rush D, Rosenberg IH. Vitamin status and intake as primary determinants of homocysteinemia in an elderly population. JAMA 1993;270:2693-2698.

34. Borch K, Kullman E, Hallhagen S, Ledin T, Inse I. Increased incidence of pancreatic neoplasia in pernicious anemia. World J Surg 1988;12:866-870.

35. Karlson BM, Ekbom A, Wacholder S, McLaughlin JK, Hsing AW. Cancer of the upper gastrointestinal tract among patients with pernicious anemia: a case-cohort study. Scand J Gastroenterol 2000;35:847-851.

36. Hsing AW, Hansson LE, McLaughlin JK, Nyren O, Blot WJ, Ekbom A, Fraumeni JF, Jr. Pernicious anemia and subsequent cancer. A population-based cohort study. Cancer 1993;71:745-750.

37. Mellemkjaer L, Gridley G, Moller H, Hsing AW, Linet MS, Brinton $\mathrm{LA}$, Olsen JH. Pernicious anaemia and cancer risk in Denmark. Br J Cancer 1996;73:998-1000.

Received August 6, 2006. Accepted September 21, 2006.

Address requests for reprints to: Susanna C. Larsson, PhD, Division of Nutritional Epidemiology, National Institute of Environmental Medicine, Karolinska Institutet, PO Box 210, SE - 17177 Stockholm, Sweden. e-mail: susanna.larsson@ki.se; fax: (46) 8-304571.

Supported by research grants from the Swedish Cancer Foundation and the Swedish Research Council/Longitudinal Studies. 